\title{
Cerrahi Hemşirelerinin Basınç Yaralarını Önlemeye Yönelik Bilgi Durumları ve Tutumları
}

\author{
Knowledge and Attitudes of Surgical Nurses towards \\ Pressure Ulcer Prevention
}

Ezgi Keser ${ }^{1}$,

Serpil Yüksel ${ }^{2}$

${ }^{1}$ Konya Eğitim ve Araştırma Hastanesi, Yazır Fizik Tedavi Kliniği, Konya, Türkiye

${ }^{2}$ Necmettin Erbakan Üniversitesi, Hemşirelik Fakültesi, Hemşirelik Bölümü, Cerrahi Hastalıkları Hemşireliği Anabilim Dalı, Konya, Türkiye

Geliş Tarihi/Received: 26 Temmuz 2019 Kabul Tarihi/Accepted: 3 Aralık 2019

Yazışma Adresi: Serpil Yüksel, Necmettin Erbakan Üniversitesi, Hemşirelik Fakültesi, Hemşirelik Bölümü, Cerrahi Hastalıkları Hemşireliği Anabilim Dalı, Konya, Türkiye e-mail: yukselserpil1977@gmail.com

\section{ORCID}

Ezgi Keser

https://orcid.org/0000-0002-9418-5063 Serpil Yüksel

https://orcid.org/0000-0001-6881-8288

\begin{abstract}
Öz
Amaç: Bu araştırmada, cerrahi hastalarına bakım veren hemşirelerin basınç yaralarını önlemeye yönelik bilgi ve tutumlarını belirlemek amaçlandı.

Gereçler ve Yöntem: Tanımlayıcı tipteki bu araştırma, Konya'da bir üniversite hastanesinin cerrahi klinik ve yoğun bakım ünitelerinde çalışan ve meslekte çalışma yılı en az bir yıl olan 150 hemşire ile gerçekleştirildi. Veriler, hasta bilgi formu, Basınç Ülserini Önlemede Bilgi Değerlendirme Ölçeği (BÜÖBDÖ) ve Basınç Ülserini Önlemeye Yönelik Tutum Ölçeği (BÜÖYTÖ) ile 1 Ekim 2018-1 Şubat 2019 tarihleri arasında toplandı. Verilerin analizinde, bağımsız gruplarda t testi, Mann Whitney $U$ test, Kruskal Wallis test, korelasyon analizi ve çoklu regresyon analizi kullanıldı.

Bulgular: Hemşirelerin yaş ortalaması $29.91 \pm 6.48$ yıl olup, \%65.3'ü kadın ve yarısı lisans mezunudur. BÜÖBDÖ toplam puan ortalamasına $(<\% 60)$ göre hemşirelerin basınç yarasını önlemeye yönelik bilgilerinin yetersiz olduğu, sadece $\% 24$ ünün bilgi puanının $\geq \% 60$ olduğu saptandı. Regresyon analiz sonuçları, hemşirelerin mesleki deneyim süresi, çalışma şekli, günlük bakım verdikleri hasta sayısı ve basınç yaralı hastaya bakım verme deneyimlerinin BÜÖBDÖ toplam puan ortalamasını anlamlı olarak etkilediğini ortaya koydu $(p<0.05)$. BÜÖYTÖ toplam puan ortalamasına $(\geq \% 75)$ göre hemşirelerin basınç ülserini önlemeye yönelik tutumlarının olumlu olduğu saptandı. Hemşirelerin tanıtıcı özelliklerinin BÜÖYTÖ toplam puan ortalamasını anlamlı olarak etkilemediği belirlendi $(p>0.05)$. BÜÖBDÖ ile BÜÖYTÖ toplam puan ortalamaları arasında anlamlı ilişki saptanmadı $(p>0.05)$.

Sonuç: Bu araştırma, cerrahi hemşirelerinin basınç yaralarını önlemeye yönelik tutumlarının olumlu, bilgilerinin ise yetersiz olduğunu ortaya koydu.
\end{abstract}

Anahtar Kelimeler: Basınç yarası, Bilgi, Hemşirelik, Önlem, Tutum

Abstract

Aim: The aim of this study was to determine pressure ulcer prevention knowledge and attitudes among nurses who cared for surgical patients.

Materials and Methods: This descriptive study was carried out with 150 nurses who were working in the surgical clinics and surgical intensive care units of a medical faculty hospital in Konya and who had at least one year's professional experience. Data were collected with a patient information form, the Pressure Ulcer Prevention Knowledge Assessment Instrument (PUPKAI) and the Attitude towards Pressure ulcer Prevention instrument (APuP) between October 1, 2018 and February 1, 2019. Data were analyzed with the independent-samples t-test, the Mann-Whitney $U$ test, the Kruskal-Wallis test, the correlation analysis and the multiple regression analysis.

Results: The mean age of the nurses was $29.91 \pm 6.48$ years, $65.3 \%$ were female and half of them had undergraduate degrees. According to the PUPKAI total mean score $(<60 \%)$, the pressure ulcer prevention knowledge of the nurses was inadequate and only $24 \%$ had a knowledge score $\geq 60 \%$. Regression analysis results showed that, nurses' professional experience duration, working style, number of patients per shift and the experiences of giving care to patients with pressure ulcers were found to have a significant effect on the PUPKAl total mean score $(p<0.05)$. According to the APuP total mean score $(\geq 75 \%)$, the nurses had positive attitudes towards pressure ulcer prevention. It was also determined that the descriptive characteristics of the nurses did not significantly affect the APuP total mean score $(p>0.05)$. There was no significant relationship between the total mean scores of the PUPKAI and APUP $(p>0.05)$.

Conclusion: This study revealed that the surgical nurses had positive attitudes towards pressure ulcer prevention but they had inadequate knowledge about it.

Key words: Pressure ulcer, Knowledge, Nursing, Prevention, Attitude
Atıf yapmak için: Keser E, Yüksel S. Cerrahi Hemşirelerinin Basınç Yaralarını Önlemeye Yönelik Bilgi Durumları ve Tutumları. Selcuk Med J 2020;36(3): 216225

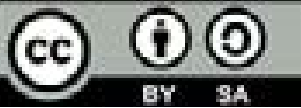

Açıklama: Yazarların hiçbiri, bu makalede bahsedilen herhangi bir ürün, aygıt veya ilaç ile ilgili maddi çıkar ilişkisine sahip değildir. Araştırma, herhangi bir dış organizasyon tarafından desteklenmedi. Yazarlar çalışmanın birincil verilerine tam erişim izni vermek ve derginin talep ettiği takdirde verileri incelemesine izin vermeyi kabul etmektedirler. 


\section{GíRiş}

Kemik çıkıntılar üzerindeki dokuların sürekli basınca maruz kalması sonucu oluşan lokalize deri veya derin doku hasarı olarak tanımlanan basınç yaraları (1), hastanede yatış süresini uzatan, tedavi ve bakım maliyetini, morbidite ve mortalite oranlarını artıran ciddi sağlık sorunlarıdır (2,3-6). Sağlık bakım kalitesinin en önemli belirteçlerinden biri olarak kabul edilen bu yaraların önlenmesi, hasta güvenliğinin sağlanmasında ve bakım memnuniyetinin artırılmasında önemlidir (2,5,79). Kalite, maliyet ve hemşirelik bakımı açısından değerlendirildiğinde; basınç yaralarını önlemenin tedaviden daha kolay ve ucuz olduğu belirtilmektedir $(2,8,10)$. Basınç yarası riskinin değerlendirilmesinde, risk faktörlerinin belirlenmesinde, risk faktörlerine yönelik önleyici girişimlerin planlanmasında ve uygulanmasında önemli rol ve sorumlulukları olan sağlık profesyonellerinden biri hemşirelerdir (2,5,9-12). Hemşirelik Yönetmeliğinde Değişiklik Yapılmasına Dair Yönetmelikte, "stoma ve yara bakım hemşiresinin basınç yarası riskini belirleme, yoğun bakım hemşiresinin basınç yarası oluşumunu önlemeye yönelik uygun hemşirelik yaklaşımını sağlama yükümlülüğünün olduğu" belirtilmektedir (13). Hemşirelerin basınç yarası risk faktörlerine ve önleme girişimlerine yönelik bilgilerinin ve tutumlarının, uygulanan önleme girişimlerini etkilediği ve basınç yaralarının insidansının azaltılmasında anahtar rol oynadığı belirtilmektedir (14-19).

Literatürde, hemşirelerin basınç yaralarını önlemeye yönelik bilgilerinin yeterli $(3,11,17,20)$, tutumlarının olumlu olduğunu (4,14-16,20,20-23) ortaya koyan çalışmalar yanında, bilgilerinin $(2,5-$ $7,9,10,12,14-16,19,23-26)$ ve tutumlarının $(9,17)$ istenen düzeyde olmadığını ortaya koyan çalışmalar da bulunmaktadır. Bu çalışmaların kapsamı değerlendirildiğinde, sadece cerrahi hemşireleri ile gerçekleştirilen çalışmaların sınırlı olduğu $(19,22)$ ve bu çalışmalara göre cerrahi hemşirelerinin basınç yaralarını önlemeye yönelik bilgilerinin yetersiz (19), tutumlarının ise olumlu olduğu $(19,22)$ belirlendi. Bu bağlamda bu araştırma, cerrahi girişim öncesi, sırası ve sonrası dönemde hareketsizlik, tıbbi araç-gereç kullanımı, beslenme sorunları ve uzun ameliyat süresi gibi basınç yarası risk faktörlerine maruz kalan cerrahi hastasına bakım veren hemşirelerin basınç yaralarını önlemeye ilişkin bilgi ve tutumlarını belirlemek ve bu alandaki sınırlı literatür bilgisine katkı sağlamak amacıyla gerçekleştirildi.

\section{GEREÇLER VE YÖNTEM}

\section{Araştırmanın Tipi, Evren ve Örneklemi}

Tanımlayıcı tipteki bu araştırmanın evrenini Konya ilinde bir üniversite hastanesinin cerrahi klinik ve cerrahi yoğun bakım ünitelerinde (YBÜ) çalışan ve en az bir yıl mesleki deneyime sahip olan 175 hemşire oluşturdu. Araştırma sürecinde evrenin tamamına ulaşılması hedeflendiğinden örnekleme yoluna gidilmedi. Araştırma verilerinin toplandığı 1 Ekim 2018-1 Şubat 2019 tarihleri arasında doğum sonu izin (11 hemşire) ve askerlik görevi (bir hemşire) nedeniyle kurumda bulunmayan 12 hemşire dışında 163 hemşireye ulaşıldı. Araştırmaya katılmayı kabul etmeyen 13 hemşire araştırma dışında bırakılarak araştırma 150 hemşire ile tamamlandı. Evrenin \%85.7'sine ulaşıldı (150/175). Çalışmanın birincil sonucu olan bilgi puanını, \%19 oranında etkilediği belirlenen dört bağımsız değişkene ilişkin regresyon değeri ( $R^{2}$ : 0.19) (Tablo 4) dikkate alınarak, $G^{*}$ Power (3.1.9.2) programı ile yapılan güç analizinde, etki büyüklüğü f2: 0.23 (orta etki), güç \%100 olarak bulundu ve örneklemin evreni temsil edecek yeterlilikte olduğu belirlendi.

\section{Veri Toplama Araçları}

Veriler, Hasta Bilgi Formu, Basınç Ülserini Önlemede Bilgi Değerlendirme Ölçeği (BÜÖBDÖ) ve Basınç Ülserini Önlemeye Yönelik Tutum Ölçeği (BÜÖYTÖ) ile toplandı.

Hasta Bilgi Formu: Araştırmacılar tarafından literatür doğrultusunda $(4,15-19,21,22,25,27-30)$ oluşturulan bu form, hemşirelerin yaş, cinsiyet, eğitim durumu, mesleki deneyim süresi, günlük bakım verilen hasta sayısı, basınç yarasına yönelik eğitim alma durumu ve basınç yaralı hastaya bakım verme deneyimi gibi tanıtıcı özelliklerini içeren 14 sorudan oluştu.

Basınç Ülserini Önlemede Bilgi Değerlendirme Ölçeği: Beeckman et al. (27) tarafından geliştirilmiş olan bu ölçeğin Türkçe uyarlaması Tülek et al. (25) tarafından yapılmıştır. Ölçek, etiyoloji ve gelişme (6 madde), sınıflandırma ve gözlem (5 madde), risk değerlendirmesi ( 2 madde), beslenme (1 madde), basınç/yırtılma miktarını azaltan girişimler ( 7 madde) ve basınç/yırtılma süresini azaltan girişimler (5 madde) olmak üzere altı tema ve 26 maddeden oluşmaktadır. Ölçekten elde edilebilecek en yüksek puan 26 olup, bilgi yeterliliği için kabul edilebilir puan $\geq 16$ (\%60)'dır $(25,27)$. Ölçeğin güvenirlik katsayısı orijinal versiyonunda 0.77 (27), Türkçe uyarlama çalışmasında 0.80 (25), bu çalışmada ise 0.32 olarak hesaplandı.

Basınç Ülserini Önlemeye Yönelik Tutum Ölçeği: 
Beeckman et al. (28) tarafından geliştirilmiş, Üstün (29) tarafından Türkçe'ye uyarlanmıştır. Ölçek, basınç yarasını önlemek için bireysel yeterlilik (3 madde), önleme önceliği ( 3 madde), basınç yarasının etkisi (3 madde), kişisel sorumluluk (2 madde), önlemenin etkinliği (2 madde) olmak üzere beş alt boyut ve 13 maddeden oluşmaktadır. Olumsuz ifadelerden oluşan yedi madde (maddeler: $3,5,7,8,9,10,13$ ) ters kodlanarak puanlanmaktadır. 4'lü likert tipteki (1: Kesinlikle katılmıyorum, 2: Katılmıyorum 3: Katılıyorum 4: Kesinlikle katılıyorum) bu ölçekten alınabilecek en düşük puan 13 , en yüksek puan ise 52 'dir. Ortalama tutum puanının $\% 75$ ve fazla olması tatmin edici kabul edilmektedir $(28,29)$. Ölçeğin güvenirlik katsayısı orijinal versiyonunda 0.79 (28), Türkçe uyarlama çalışmasında 0.71 (29), bu çalışmada ise 0.71 olarak bulunmuştur.

\section{Verilerin Toplanması}

Araştırmaya katılmayı kabul eden hemşirelere uygun olduklarını belirttikleri saatlerde, veri toplama formu verildi. Soruları yanıtlarken diğer meslektaşlarına danışmalarını veya literatür desteğine başvurmalarını önlemek amacıyla veri toplama, kliniğin seminer odasında katılımcı tek iken gerçekleştirildi. Formun doldurulma süresi ortalama 20 dakika sürdü.

\section{Verilerin Değerlendirilmesi}

Verilerin değerlendirilmesinde SPPS 20 (IBM Corp. Released 2011. IBM SPSS Statistics for Windows, Version 20.0. Armonk, NY: IBM Corp.) istatistik paket programı kullanıldı. Tanımlayıcı veriler, sayı, yüzde, ortalama, standart sapma (SS), minimum ve maksimum değerler ile sunuldu. Skewness (-1.55 ile 0.46 arası) ve Kurtosis (-0.88 ile 1.99 arası) değerlerine göre normal dağılıma (-2 ile +2 arasında) sahip olan verilerin analizinde parametrik, diğerlerinde ise parametrik olmayan testler kullanıldı. Tanıtıcı özelliklerin BÜÖBDÖ ve BÜÖYTÖ toplam puanları üzerindeki etkisinin belirlenmesinde, bağımsız gruplarda t testi, Mann Whitney $U$ testi ve Kruskal Wallis testi (ileri analizi Bonferroni düzeltmeli Mann Whitney $U$ testi) kullanıldı. Ölçek toplam puanları arasındaki ilişki Pearson Korelasyon analizi ile değerlendirildi. Tekli analizlerde (Tablo 3) BÜÖBDÖ toplam puanını anlamlı olarak etkilediği belirlenen sekiz yordayıcı (bağımsız) değişkenin, BÜÖBDÖ toplam puanına etkisini birlikte değerlendirmek ve BÜÖBDÖ toplam puanı üzerindeki belirleyicilik oranlarını saptamak için ileri analiz olan çoklu regresyon analizi-geriye doğru eleme (backward) yöntemi uygulandı. Tüm analizlerde önemlilik düzeyi $\mathrm{p}<0.05$ olarak kabul edildi.

\section{Etik Konular}

Araştırmanın uygulanabilmesi için, Necmettin Erbakan Üniversitesi Meram Tıp Fakültesi İlaç ve Tibbi Cihaz Dışı Araştırmalar Etik Kurul'undan (Tarih/Sayı: 2018/1577) ve hastane başhekimliğinden (Tarih/Sayı: 2018/45211) izin alındı. BÜÖBDÖ ve BÜÖYTÖ'nin araştırmada kullanımı için Türkçe uyarlamasını yapan yazarlardan izin alındı. Araştırmaya katılmayı kabul eden hemşireler, araştırmanın amacı ve araştırmaya katılımın gönüllülük ilkesi doğrultusunda olduğu konusunda bilgilendirildi ve "Gönüllülerin Bilgilendirilmesi ve Rızası'nın Alınması Olur Formu" imzalatıldı.

\section{BULGULAR}

Hemşirelerin yaş ortalaması $29.91 \pm 6.48$ yıl olup, yarısından fazlası (\%52.7) 30 yaş ve altındadır ve \%65.3'ü kadındır. Yarısı lisans mezunudur ve \%58.7'sinin mesleki deneyim süresi beş yıldan fazladır. Çoğunluğu (\%90) cerrahi kliniklerde çalışmaktadır ve \%53.3'ü günde 10 ve daha fazla sayıda hastaya bakım vermektedir. Hemşirelerin \%61.3'ünün basınç yarası ve önlenmesine ilişkin okulda öğrencilik yıllarında eğitim aldığı, çoğunluğunun (\%90.7) basınç yaralı hastaya bakım verme deneyiminin olduğu, ancak sadece \%28'inin basınç yarası riskini yeterli sıklıkta değerlendirdiği belirlendi. Basınç yarası riskini artıran faktörlere ilişkin soru hemşirelerin \%31.3'ü tarafından yanıtlanmadı. Yanıt veren hemşireler basınç yarası gelişiminde etkili risk faktörlerini sırasıyla aynı pozisyonda yatma, obezite, yetersiz beslenme, gaita ve idrar inkontinansı olarak belirtti. Kurumlarında uygulanan basınç yarası önleme girişimlerine hemşirelerin \%34'ünden yanıt gelmedi. Bu soruyu yanıtlayanlar bu girişimleri sırasıyla pozisyon değişimi ve mobilizasyon, günlük deri değerlendirmesi ve bakımı, destek yüzey kullanımı ve protein ağırlıklı beslenme olarak belirtti (Tablo 1).

Hemşirelerin BÜÖBDÖ toplamından ortalama $52.87 \pm 11.13$ puan, BÜÖYTÖ toplamından ise ortalama $80.53 \pm 8.38$ puan aldığı ve basınç yaralarını önlemeye yönelik bilgilerinin yetersiz ( $<\% 60$ puan), tutumlarının ise olumlu olduğu ( $\geq \% 75$ puan) belirlendi. Ölçeklerin kesim noktasına göre yapılan değerlendirmede, hemşirelerin çoğunluğunun (\%78) basınç yaralarını önlemeye yönelik tutumunun olumlu olduğu, ancak sadece \%24'ünün bilgisinin yeterli olduğu saptandı. BÜÖBDÖ ile BÜÖYTÖ toplam puan ortalamaları arasında anlamlı ilişki saptanmadı ( $p>0.05$, Tablo 2).

Hemşirelerin BÜÖBDÖ temalarından en düşük 
Tablo 1. Hemşirelerin tanıtıcı özellikleri $(n=150)$

\begin{tabular}{|c|c|c|}
\hline Özellikler & $\mathbf{n}$ & $\%$ \\
\hline \multicolumn{3}{|l|}{ 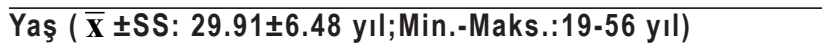 } \\
\hline$<30$ yıl & 79 & 52.7 \\
\hline$\geq 30$ yıl & 71 & 47.3 \\
\hline \multicolumn{3}{|l|}{ Cinsiyet } \\
\hline Erkek & 52 & 34.7 \\
\hline Kadın & 98 & 65.3 \\
\hline \multicolumn{3}{|l|}{ Eğitim durumu } \\
\hline Lise & 44 & 29.3 \\
\hline Önlisans & 26 & 17.3 \\
\hline Lisans & 75 & 50.0 \\
\hline Lisans üstü & 5 & 3.3 \\
\hline \multicolumn{3}{|l|}{ Mesleki deneyim süresi } \\
\hline $1-5$ yıl & 62 & 41.3 \\
\hline$>5 \mathrm{yıl}$ & 88 & 58.7 \\
\hline \multicolumn{3}{|l|}{ Şu an çalıştığı birim } \\
\hline Klinik* & 90 & 60.0 \\
\hline Yoğun bakım** & 60 & 40.0 \\
\hline \multicolumn{3}{|l|}{ Şu an bulunduğu birimde çalışma yılı } \\
\hline$\leq 4$ yıl & 91 & 60.7 \\
\hline$>4 \mathrm{y}$ Il & 59 & 39.3 \\
\hline \multicolumn{3}{|l|}{ Çalıştığı birimdeki görevi } \\
\hline Klinik hemşiresi & 139 & 92.7 \\
\hline Sorumlu hemşire & 11 & 7.3 \\
\hline \multicolumn{3}{|l|}{ Çalışma şekli } \\
\hline Sürekli gündüz & 18 & 12.0 \\
\hline Gündüz ve gece & 132 & 88.0 \\
\hline \multicolumn{3}{|l|}{ Günlük bakım verilen hasta sayısı } \\
\hline$<10$ hasta & 70 & 46.7 \\
\hline$\geq 10$ hasta & 80 & 53.3 \\
\hline \multicolumn{3}{|c|}{ Basınç yarası ve önlenmesine ilişkin eğitim alma durumu } \\
\hline Eğitim almadı & 12 & 8.0 \\
\hline Okulda eğitim aldı & 92 & 61.3 \\
\hline Hizmet içi eğitim aldı & 46 & 30.7 \\
\hline \multicolumn{3}{|l|}{ Basınç yaralı hastaya bakım verme deneyimi } \\
\hline Bakım vermemiş & 14 & 9.3 \\
\hline Bakım vermiş & 136 & 90.7 \\
\hline \multicolumn{3}{|l|}{$\begin{array}{l}\text { Basınç yarası riskini değerlendirme sıklığı } \\
\text { Yetersiz (ilk yatışta veya genel }\end{array}$} \\
\hline $\begin{array}{l}\text { Yetersiz (ilk yatışta veya genel } \\
\text { durum değiştikçe) }\end{array}$ & 108 & 72.0 \\
\hline \multicolumn{3}{|l|}{ Yeterli (ilk yatışta, genel durumu } \\
\hline değiştikçe ve nakil/taburculukta) & 42 & 28.0 \\
\hline \multicolumn{3}{|l|}{ Basınç yarası riskini artıran faktörler ${ }^{* * *}$} \\
\hline Yanıt yok & 47 & 31.3 \\
\hline Aynı pozisyonda yatma & 57 & 38.0 \\
\hline Obezite & 41 & 27.3 \\
\hline Yetersiz beslenme & 39 & 26.0 \\
\hline Gaita-idrar inkontinansı & 17 & 11.3 \\
\hline \multicolumn{3}{|c|}{ Kurumda uygulanan basınç yarası önleme girişimleri*** } \\
\hline Yanıt yok & 51 & 34.0 \\
\hline Pozisyon değişimi ve mobilizasyon & 70 & 46.7 \\
\hline Günlük deri değerlendirmesi ve bakımı & 50 & 33.3 \\
\hline Destek yüzey kullanımı & 16 & 10.7 \\
\hline Protein ağırlıklı beslenme & 14 & 9.3 \\
\hline
\end{tabular}

$\overline{\mathbf{x}}$ : Ortalama, Min.: Minimum, Maks.: Maksimum, SS: Standart Sapma. *Klinikler: Genel cerrahi, Üroloji, Kardiyovasküler cerrahi, Gögüus cerrahi, Ortopedi, Plastik cerrahi, Beyin cerrahi, Kulak burun boğaz, Göz.

**Yoğun bakım üniteleri: Genel cerrahi, Kardiyovasküler cerrahi, Anestezi ve Reanimasyon, Beyin Cerrahi, Göğüs Cerrahi.

***Birden fazla seçenek işaretlenmiştir. puan ortalamasını "basınç/yırtılma miktarını azaltan girişimler"(45.14 \pm 20.07$)$ temasından aldığı ve \%82'sinin bu temada yer alan önleme girişimlerine ilişkin bilgilerinin yeterli olmadığı belirlendi. En yüksek puan ortalamasını ise "risk değerlendirmesi" (73.67 \pm 29.37$)$ temasından aldıkları saptandı. Hemşirelerin BÜÖYTÖ "bireysel yeterlilik" alt boyutu dışında tüm alt boyutlarda tutumlarının olumlu olduğu, en düşük puan ortalamasını "bireysel yeterlilik" (67.33 \pm 14.66$)$, en yüksek puan ortalamasını ise "basınç yarasının etkisi" (90.17 \pm 11.75$)$ boyutundan aldıkları belirlendi (Tablo 2).

Hemşirelerin tanıtıcı özelliklerinin BÜÖYTÖ toplam puan ortalamasını anlamlı olarak etkilemediği saptandı ( $p>0.05$, Tablo 3). BÜÖBDÖ toplam puan ortalamasını ise, yaş, mesleki deneyim süresi, şu an bulunduğu birimde çalışma yılı, çalıştığı birimdeki görevi, çalışma şekli, günlük bakım verilen hasta sayısı, basınç yaralı hastaya bakım verme deneyimi ve risk değerlendirme sıklığı değişkenlerinin anlamlı olarak etkilediği belirlendi $(p<0.05$, Tablo 3$)$. Tekli analizlerde etkisi gösterilen bu değişkenlerin (Tablo 3) BÜÖBDÖ toplam puanı üzerindeki belirleyicilik oranları çoklu regresyon analizi ile birlikte değerlendirildiğinde, sadece mesleki deneyim süresi, çalışma şekli, günlük bakım verilen hasta sayısı ve basınç yaralı hastaya bakım verme deneyiminin bilgi puan ortalamasını anlamlı olarak \%19 oranında ( $\left.R^{2}: 0.19\right)$ etkilediği saptandı (F: 9.52, p< 0.001, Tablo 4). Bu değişkenlerden BÜÖBDÖ toplam puan ortalamasına en fazla katkıyı mesleki deneyim süresinin $(\beta=0.28)$, en az katkıyı ise basınç yaralı hastaya bakım verme deneyiminin $(\beta=0.15)$ sağladığı belirlendi (Tablo 4).

Regresyon katsayılarına (B) göre (Tablo 4), mesleki deneyim süresi beş yıl ve daha az olanlar ile kıyaslandığında, deneyimi beş yıldan fazla olanların BÜÖBDÖ toplam puan ortalamasının 6.29 puan, gece ve gündüz karma çalışanlara göre sürekli gündüz çalışanların puanının 6.05 puan daha fazla olduğu belirlendi. Günlük 10 hastadan daha $a z$ sayıda hastaya bakım veren hemşirelerin BÜÖBDÖ toplam puan ortalamasının 10 ve daha fazla sayıda hastaya bakım verenlere göre 3.71 puan, basınç yaralı hastaya bakım verme deneyimi olanların bilgi puanının ise deneyimi olmayanlara göre 5.77 puan daha fazla olduğu saptandı (Tablo 4).

\section{TARTIŞMA}

Basınç yaralarının önlenmesi, hemşirelik bakım kalitesinin göstergelerinden biri olarak kabul edilmektedir $(5,7,9,11)$. Bu yaraların önlenmesinde, 
Tablo 2. Hemşirelerin BÜÖBDÖ ve BÜÖYTÖ puan ortalamaları ve aralarındaki ilişki $(n=150)$

\begin{tabular}{|c|c|c|c|c|c|c|}
\hline \multirow{3}{*}{ вÜÖBDÖ Temaları } & \multirow{3}{*}{ Min.-Maks.* } & \multirow{3}{*}{$\overline{\mathbf{X}} \pm \mathbf{S S}$} & \multicolumn{4}{|c|}{ Kesme Noktas $I^{* *}$} \\
\hline & & & \multirow[b]{2}{*}{$\mathbf{n}$} & \multirow{2}{*}{$\begin{array}{l}<\% 60 \\
\%\end{array}$} & \multicolumn{2}{|c|}{$\geq \% 60$} \\
\hline & & & & & $\mathbf{n}$ & $\%$ \\
\hline Tema1. Etiyoloji ve gelişme & $0-100$ & $50.44 \pm 20.61$ & 104 & 69.3 & 46 & 30.7 \\
\hline Tema2. Sınıflandırma ve gözlem & $0-100$ & $57.33 \pm 21.32$ & 53 & 35.3 & 97 & 64.7 \\
\hline Tema3. Risk değerlendirmesi & $0-100$ & $73.67 \pm 29.37$ & 72 & 48.0 & 78 & 52.0 \\
\hline Tema4. Beslenme & $0-100$ & $73.33 \pm 44.37$ & 40 & 26.7 & 110 & 73.3 \\
\hline Tema5.Basınç/yırtılma miktarını azaltan girişimler & $0-100$ & $45.14 \pm 20.07$ & 123 & 82.0 & 27 & 18.0 \\
\hline Tema6.Basınç/yırtılma süresini azaltan girişimler & $0-100$ & $49.73 \pm 20.69$ & 75 & 50.0 & 75 & 50.0 \\
\hline \multirow[t]{2}{*}{ BÜÖBDÖ Toplamı } & $26.9-96.2$ & $52.87 \pm 11.13$ & 114 & 76.0 & 36 & 24.0 \\
\hline & \multirow{3}{*}{ Min.-Maks.* } & \multirow{3}{*}{$\overline{\mathbf{x}} \pm \mathbf{S S}$} & \multicolumn{4}{|c|}{ Kesme Noktası*** } \\
\hline \multirow[t]{2}{*}{ BÜÖYTÖ Alt Boyutları } & & & \multicolumn{4}{|c|}{$<\% 75 \geq \% 75$} \\
\hline & & & $\mathbf{n}$ & $\%$ & $\mathbf{n}$ & $\%$ \\
\hline Bireysel yeterlilik & $33.3-100$ & $67.33 \pm 14.66$ & 88 & 58.7 & 62 & 41.3 \\
\hline Önleme önceliği & $50-100$ & $80.89 \pm 12.65$ & 28 & 18.7 & 122 & 81.3 \\
\hline Basınç yarasının etkisi & $41.67-100$ & $90.17 \pm 11.75$ & 7 & 4.7 & 143 & 95.3 \\
\hline Kişisel sorumluluk & $50-100$ & $82.92 \pm 11.26$ & 17 & 11.3 & 133 & 88.7 \\
\hline Önlemenin etkinliği & $25-100$ & $82.92 \pm 13.23$ & 15 & 10.0 & 135 & 90.0 \\
\hline BÜÖYTÖ Toplamı & $57.69-100$ & $80.53 \pm 8.38$ & 33 & 22.0 & & 78.0 \\
\hline \multicolumn{2}{|l|}{ BÜÖYTÖ Toplam Puanı \& BÜÖBDÖ Toplam Puanı: } & & \multicolumn{2}{|c|}{$r:-0.04$} & \multicolumn{2}{|c|}{ p: 0.615} \\
\hline
\end{tabular}

$\overline{\overline{\mathbf{x}}}$ : Ortalama, Min.: Minimum, Maks.: Maksimum, r: Pearson Korelasyon Analizi, SS: Standart Sapma.

BÜÖBDÖ: Basınç Ülserini Önlemede Bilgi Değerlendirme Ölçeği, BÜÖYTÖ: Basınç Ülserini Önlemeye Yönelik Tutum Ölçeği.

*Toplam puan ve alt boyut/tema puanları 100'e dönüştürülmüştür.

**Bilgi yeterliliği için kabul edilebilir puan $\geq \% 60$ 'dır.

***Ortalama tutum puanının \%75 ve fazla olması tatmin edici kabul edilmektedir.

bakımın birincil sorumlusu olan hemşirelerin basınç yaralarını önlemeye yönelik olumlu tutum geliştirmelerinin ve kanıt temelli önleme girişimleri hakkında yeterli bilgiye sahip olmalarının etkili olduğu bildirilmiştir (12,14,16-19,21). Cerrahi birimlerde çalışan hemşirelerin basınç yaralarını önlemeye yönelik bilgi ve tutumlarını belirlemek amacıyla gerçekleştirilen bu araştırmada, hemşirelerin bilgilerinin yeterli olmadığı, ancak tutumlarının olumlu olduğu belirlendi.

\section{Hemşirelerin basınç yaralarını önlemeye yönelik bilgi ve tutumları}

Literatürde, hemşirelerin basınç yaralarını önlemeye yönelik bilgilerinin ve tutumlarının değerlendirildiği çok sayıda çalışma olmasına rağmen, sadece cerrahi birimlerde çalışan hemşirelerin bilgi ve tutumlarını inceleyen sınırlı sayıda çalışmaya rastlandı. Bu çalışmaların bulguları da, araştırmamıza benzer şekilde cerrahi hemşirelerinin basınç yaralarını önlemeye yönelik tutumlarının olumlu $(19,22)$, bilgilerinin ise yetersiz (19) olduğunu ortaya koymuştur. Cerrahi klinik ve YBÜ'leri dışında diğer klinik ve YBÜ'lerinde çalışan hemşirelerin de dahil edildiği birçok çalışmada da araştırmaya benzer şekilde, hemşirelerin basınç yaralarını önlemeye yönelik bilgilerinin yetersiz $(2,5-7,9,10,12,14-16,23$ 26), tutumlarının ise olumlu $(4,14-16,20,20-23)$ olduğu bildirilmiştir. Ek olarak araştırmada, ölçeklerin kesim noktalarına göre, hemşirelerin çoğunluğunun (\%78) tutumlarının olumlu (>\%75 puan) olduğu, ancak sadece \%24'ünün bilgi puanının ( $>\% 60$ puan) yeterli olduğu da saptandı. Benzer çalışmalarda da, hemşirelerin \%82.29'unun tutumunun olumlu olduğu (16), sadece \%23.5-27'sinin bilgisinin yeterli olduğu $(14,24)$ belirlenmiştir.

Araştırmadan farklı olarak literatürde, hemşirelerin basınç yaralarını önlemeye yönelik bilgilerinin yeterli olduğunu $(3,11,17,20)$, tutumlarının ise tatmin edici olmadığını $(9,17)$ ortaya koyan çalışmalar da bulunmaktadır. Farkın nedeni, bu çalışmalarda farklı değerlendirme araçlarının $(3,11,17)$ veya BÜÖBDÖ'nin revize formunun kullanılması (20), hemşirelerin çoğunluğunun (\%78) basınç yaralarının önlenmesi ile ilgili sürekli eğitim alması (20), çalışma kapsamına hemşire dışındaki diğer sağlık profesyonellerinin (17) veya sadece YBÜ hemşirelerinin (9) dahil edilmesi olabilir. Araştırmada, hemşirelerin BÜÖBDÖ'nin altı alt temasından sadece "risk değerlendirmesi" ve "beslenme" temalarındaki girişimler hakkında bilgilerinin yeterli olduğu belirlendi. Mevcut çalışmalara $(7,25)$ benzer şekilde hemşireler en düşük puanı "basınç/ yırtılma miktarını azaltan girişimler" temasından, en yüksek puanı ise Demarre et al. (15)'nın çalışmasına benzer şekilde 
Tablo 3. Hemşirelerin tanıtıcı özellikleri ile BÜÖBDÖ ve BÜÖYTÖ puan ortalamalarının karşılaştırılması $(n=150)$

\begin{tabular}{|c|c|c|c|}
\hline Tanıtıcı Özellikler & $\mathbf{n}$ & $\begin{array}{c}\text { BÜÖBDÖ Toplam Puanı* } \\
\overline{\mathbf{x}} \pm S S\end{array}$ & $\begin{array}{c}\text { BÜÖYTÖ Toplam Puanı* } \\
\qquad \overline{\mathbf{x}} \pm S S\end{array}$ \\
\hline \multicolumn{4}{|c|}{ 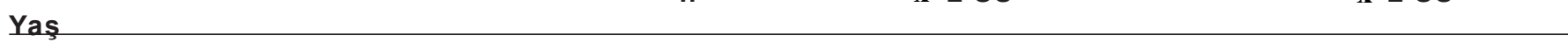 } \\
\hline$<30 y_{\prime \prime l}$ & 79 & $50.10 \pm 9.89$ & $79.67 \pm 8.62$ \\
\hline$\geq 30 y_{\prime \prime l}$ & 71 & $55.96 \pm 11.68$ & $81.47 \pm 8.06$ \\
\hline$t / p$ & & $3.297 / 0.001$ & $1.317 / 0.190$ \\
\hline \multicolumn{4}{|l|}{ Cinsiyet } \\
\hline Erkek & 52 & $53.11 \pm 12.12$ & $80.18 \pm 7.93$ \\
\hline Kadın & 98 & $52.75 \pm 10.64$ & $80.71 \pm 8.64$ \\
\hline$t / p$ & & $0.187 / 0.852$ & $0.370 / 0.712$ \\
\hline \multicolumn{4}{|l|}{ Eğitim durumu } \\
\hline Lise ve önlisans & 70 & $53.13 \pm 11.90$ & $79.31 \pm 8.02$ \\
\hline Lisans ve üstü & 80 & $52.64 \pm 10.49$ & $81.59 \pm 8.58$ \\
\hline$t / p$ & & $0.267 / 0.790$ & $1.668 / 0.097$ \\
\hline \multicolumn{4}{|l|}{ Mesleki deneyim süresi } \\
\hline $1-5$ yıl & 62 & $48.20 \pm 8.86$ & $79.62 \pm 8.76$ \\
\hline$>5$ yıl & 88 & $56.16 \pm 11.44$ & $81.16 \pm 8.09$ \\
\hline$t / p$ & & $4.800 /<0.001$ & $1.110 / 0.269$ \\
\hline \multicolumn{4}{|l|}{ Şu an çalıştığı birim } \\
\hline Klinik & 90 & $51.71 \pm 11.50$ & $81.05 \pm 8.94$ \\
\hline Yoğun bakım & 60 & $54.62 \pm 10.40$ & $79.74 \pm 7.46$ \\
\hline$t / p$ & & $1.574 / 0.118$ & $0.933 / 0.352$ \\
\hline \multicolumn{4}{|c|}{ Şu an bulunduğu birimde çalışma yılı } \\
\hline$\leq 4 \mathrm{y} / \mathrm{l}$ & 91 & $50.97 \pm 10.35$ & $79.95 \pm 8.50$ \\
\hline$>4 \mathrm{yIl}$ & 59 & $55.80 \pm 11.74$ & $81.42 \pm 8.16$ \\
\hline$t / p$ & & $2.647 / 0.009$ & $1.055 / 0.293$ \\
\hline \multicolumn{4}{|l|}{ Çalıştığı birimdeki görevi } \\
\hline Klinik hemşiresi & 139 & $52.24 \pm 11.05$ & $80.20 \pm 8.38$ \\
\hline Sorumlu hemşire & 11 & $60.84 \pm 9.23$ & $84.62 \pm 7.50$ \\
\hline$t / p$ & & $2.612 / 0.009$ & $1.793 / 0.073$ \\
\hline \multicolumn{4}{|l|}{ Çalışma şekli } \\
\hline Sürekli gündüz & 18 & $60.90 \pm 10.15$ & $82.59 \pm 8.64$ \\
\hline Gündüz ve gece & 132 & $51.78 \pm 10.84$ & $80.24 \pm 8.33$ \\
\hline $\mathrm{Z} / \mathrm{p}$ & & $3.294 / 0.001$ & $1.175 / 0.240$ \\
\hline \multicolumn{4}{|c|}{ Günlük bakım verilen hasta sayısı } \\
\hline$<10$ hasta & 70 & $54.95 \pm 10.31$ & $79.64 \pm 7.33$ \\
\hline$\geq 10$ hasta & 80 & $51.06 \pm 11.56$ & $81.30 \pm 9.17$ \\
\hline$t / p$ & & $2.160 / 0.032$ & $1.209 / 0.228$ \\
\hline \multicolumn{4}{|c|}{$\begin{array}{l}\text { Basınç yarası ve önlenmesine ilişkin } \\
\text { eğitim alma durumu }\end{array}$} \\
\hline Eğitim almadı & 12 & $51.28 \pm 16.26$ & $80.61 \pm 9.75$ \\
\hline Okulda eğitim aldı & 92 & $52.93 \pm 9.55$ & $79.91 \pm 8.24$ \\
\hline Okulda ve kurumda eğitim aldı & 46 & $53.18 \pm 12.67$ & $81.73 \pm 8.33$ \\
\hline $\mathrm{KW} / \mathrm{p}$ & & $1.446 / 0.485$ & $1.878 / 0.391$ \\
\hline \multicolumn{4}{|l|}{$\begin{array}{l}\text { Basınç yaralı hastaya bakım } \\
\text { verme deneyimi }\end{array}$} \\
\hline Bakım vermiş & 14 & $53.65 \pm 11.21$ & $80.66 \pm 8.45$ \\
\hline Bakım vermemiş & 136 & $45.33 \pm 6.94$ & $79.26 \pm 7.81$ \\
\hline $\mathrm{Z} / \mathrm{p}$ & & $2.943 / 0.003$ & $0.661 / 0.509$ \\
\hline \multicolumn{4}{|c|}{ Basınç yarası riskini değerlendirme sıklığı } \\
\hline Yetersiz & 108 & $50.85 \pm 11.11$ & $80.95 \pm 8.48$ \\
\hline Yeterli & 42 & $58.06 \pm 9.95$ & $79.44 \pm 8.10$ \\
\hline$t / p$ & & $3.707 /<0.001$ & $0.989 / 0.503$ \\
\hline
\end{tabular}

$\overline{\overline{\mathbf{x}}}$ : Ortalama, KW: Kruskal Wallis Testi, SS: Standart Sapma, t: Bağımsız Gruplarda t Testi, Z: Mann Whitney U Testi.

BÜÖBDÖ: Basınç Ülserini Önlemede Bilgi Değerlendirme Ölçeği, BÜÖYTÖ: Basınç Ülserini Önlemeye Yönelik Tutum Ölçeği.

"risk değerlendirmesi" temasından aldı. Hemşirelerin "risk değerlendirme" temasından aldığı puan yüksek olmasına rağmen, risk faktörlerine ilişkin sorunun yanıtlanmaması (\%31.3), pozisyon (\%38), yetersiz beslenme (\%26) ve inkontinans (\%11.3) gibi kanıt temelli risk faktörlerinin belirtilme oranının düşük 
Tablo 4. Çoklu regresyon analizi sonuçlarına göre hemşirelerin BÜÖBDÖ toplam puan ortalamasını etkileyen faktörler ( $n=$ 150)

\begin{tabular}{|c|c|c|c|c|}
\hline $\begin{array}{l}\text { BÜÖBDÖ toplam puan ortalamasını } \\
\text { etkileyen (yordayıcı) bağımsız değişkenler }\end{array}$ & B & $\beta$ (Beta) & $t$ & $p$ \\
\hline (Sabit) & 19.68 & & 3.056 & 0.003 \\
\hline $\begin{array}{l}\text { Mesleki deneyim süresi } \\
(0=1-5 \text { yıl, } 1=5 \text { yıldan fazla })\end{array}$ & 6.29 & 0.28 & 3.607 & $<0.001$ \\
\hline $\begin{array}{l}\text { Çalışma şekli ( } 0=\text { Gündüz ve gece, } \\
1=\text { Sürekli gündüz) }\end{array}$ & 6.05 & 0.18 & 2.300 & 0.023 \\
\hline $\begin{array}{l}\text { Günlük bakım verilen hasta sayısı } \\
(0=10 \text { hasta ve üzeri, } 1=10 \text { hastadan az) }\end{array}$ & 3.71 & 0.17 & 2.257 & 0.026 \\
\hline \multirow{2}{*}{$\begin{array}{l}\text { Basınç yaralı hastaya bakım verme deneyimi } \\
(0=\text { Bakım vermemiş, } 1=\text { Bakım vermiş })\end{array}$} & 5.77 & 0.15 & 2.017 & 0.046 \\
\hline & $R=0.46$ & $\mathrm{R}^{2}=0.19$ & $F=9.52$ & $p<0.001$ \\
\hline
\end{tabular}

BÜÖBDÖ: Basınç Ülserini Önlemede Bilgi Değerlendirme Ölçeği

B: Regresyon katsayısı, $\beta$ (Standardize Beta): Kısmi regresyon katsayısı, t: Regresyon katsayıları için anlamlılık testi

p: İstatistiksel anlamlııı değeri (<0.05), R: Illişki Düzeyi, F: Varyans Analizi, R² (Düzeltilmiş R²) : Belirlilik (Determinasyon) Katsayısı

olması ve hastaların basınç yarası riskini sadece \%28'inin yeterli sıklıkta değerlendirmesi, hemşirelerin basınç yarası risk faktörleri ve risk değerlendirme sıklığı konularında bilgilendirilme gereksinimlerinin olduğunu göstermektedir. Ek olarak, hemşirelerin \%46.7'si basınç yaralarını önlemede pozisyon değişimi ve mobilizasyonun etkili olduğunu belirtmesine rağmen, en düşük puanın pozisyon verme ve değiştirme sıklığı ile ilgili soruların yer aldığı "basınç/ yırtılma miktarını azaltan girişimler" temasından alınması da, hemşirelerin verilebilecek pozisyonlar, özellikleri ve değiştirme sıklığına ilişkin bilgilerinin yeterli olmadığını göstermesi bakımından önemlidir. Düzenlenecek eğitim programları ile hemşirelerin bu eksiklikleri giderilmeli, basınç yarası risk faktörleri ve bu faktörlere temellendirilmiş önleme girişimleri konularında yetkinlikleri artırılmalıdır.

Hemşirelerin BÜÖYTÖ alt boyutundan "bireysel yeterlilik" dışında tüm boyutlarda tutumlarının olumlu olduğu belirlendi. En düşük puanın "bireysel yeterlilik" (20), en yüksek puanın ise "basınç yarasının etkisi" $(5,22)$ boyutundan alındığını ortaya koyan literatüre benzer şekilde araştırmada, hemşireler en düşük puanı "bireysel yeterlilik", en yüksek puanı ise "basınç yarasının etkisi" boyutundan aldı. Bu bulgular, hemşirelerin basınç yaralarının yıkıcı etkilerinin farkında olduklarını, ancak basınç yaralarını önlemeye yönelik bilgi ve becerilerine güvenmediklerini, basınç yaralarını önleyebileceklerine inanmadıklarını göstermektedir. Hemşirelerin basınç yaralarını önlemeye yönelik bilgi ve becerilerini artırarak bireysel yeterliliklerini geliştirmeye yönelik planlamalar yapılmalıdır.

\section{Hemşirelerin bilgi ve tutumlarını etkileyen faktörler}

Hemşirelerin cinsiyet $(9,5,23)$, eğitim düzeyi $(5,610,23,24,26)$ ve basınç yarası ile ilgili eğitim alma durumunun $(8-10,17,24,25)$ basınç yaralarını önlemeye yönelik bilgilerini anlamlı olarak etkilemediğini belirten çalışmalara benzer şekilde araştırmada, bu değişkenlerin bilgi puanını etkilemediği belirlendi. Farklı eğitim derecelerine (lise, ön lisans, lisans, bilim uzmanı, doktora) sahip olmanın ve basınç yarası ile ilgili eğitim almanın, hemşirenin görev, yetki ve sorumluluk alanında olan basınç yaralarını önlemeye yönelik bilgilerini anlamlı olarak etkilemediğini ortaya koyan araştırma bulgusu ve mevcut literatür bilgisi, mezuniyet öncesi ve sonrası eğitim programlarının içeriklerinin gözden geçirilmesinin ve düzenli aralıklarla bu eğitimlerin tekrarlanmasının önemine dikkati çekmektedir. Literatürde, araştırmadan farklı olarak eğitim düzeyi yüksek olanların $(3,30)$ ve basınç yarasını önlemeye ilişkin eğitim alanların $(3,5)$ bilgi puanının daha yüksek olduğunu bildiren çalışmalar da yer almaktadır. Farkın nedeni, hemşirelik eğitim müfredatının ve hizmet içi eğitim içeriklerinin, kurumlar ve ülkeler arasında farklılık göstermesi olabilir. Hemşirelerin mesleki deneyim süresinin $(5,9,10,11,17,23,24)$ ve yaşının $(5,6,9,10,24)$ basınç yaralarını önlemeye yönelik bilgi puanını anlamlı olarak etkilemediğini, 30 yaş altındakilerin puanının anlamlı olarak daha yüksek olduğunu (17) belirten çalışmalardan farklı olarak, mesleki deneyimi beş yıldan daha fazla olan hemşirelerin, 30 yaş ve üzerindekilerin puanının daha yüksek olduğu saptandı. Ek olarak araştırmada, bulunduğu birimde dört yıldan daha uzun süredir çalışanların, sorumlu hemşirelerin, sürekli gündüz çalışanların, günde 10 'dan daha az sayıda hastaya 
bakım verenlerin, basınç yaralı hastaya bakım verme deneyimi olanların ve basınç yarası riskini yeterli sıklıkta değerlendirenlerin bilgi puanının anlamlı olarak daha yüksek olduğu da belirlendi.

Hemşirelerin bilgi puanını etkileyen bu değişkenlerin etkisi çoklu regresyon analizi ile değerlendirildiğinde sadece, mesleki deneyim süresi, çalışma şekli, günlük bakım verilen hasta sayısı ve basınç yaralı hastaya bakım verme deneyiminin BÜÖBDÖ puanını anlamlı olarak \%19 oranında etkilediği belirlendi. Literatürde, hemşirelerin basınç yaralarını önlemeye yönelik bilgilerini etkileyen değişkenlerin regresyon analizi ile değerlendirildiği sınırlı sayıda çalışmaya $(3,14,15,19,30)$ rastlandı. Bu çalışmalardan mesleki deneyim süresi 11-20 yıl arasında olanların bilgi puanının, deneyimi 10 yıl ve daha az olanlardan 4.8 kat daha fazla olduğunu bildiren çalışmaya (3) paralel olarak araştırmada, mesleki deneyimi beş yıldan fazla olan hemşirelerin bilgi puanının deneyimi daha az olanlardan 6.29 puan daha fazla olduğu belirlendi. Mesleki deneyim süresindeki artış beraberinde tecrübeyi de getirdiğinden basınç yaralarını önlemeye yönelik bilgiyi olumlu yönde etkileyebilmektedir. Mesleki deneyim süresi fazla olan hemşirelerin basınç yaraları ve önlenmesine ilişkin bilgi puanının anlamlı olarak daha yüksek olduğunu ortaya koyan literatür bilgisi (3) de bu düşünceyi desteklemektedir. Ancak, deneyimli hemşirelerin bilgisinin hizmet içi eğitimler ile güncellenmemesi deneyimin bu etkisini gölgeleyebileceğinden, ileri yaştaki hemşirelerin ve mesleki deneyimi fazla olanların da basınç yaraları ve önlenmesine ilişkin bilgilerini güncel tutacak düzenlemeler yapılmalıdır.

Literatürde, çalışma şekli, günlük bakım verilen hasta sayısı ve basınç yarası oluşan hastaya bakım verme deneyiminin etkisinin değerlendirdiği çalışmaya rastlanmadı. Mevcut regresyon çalışmalarında araştırmadan farklı olarak, eğitim düzeyi yüksek olanların $(3,30)$ ve basınç yarasını önlemeye ilişkin formal eğitim alanların (3) bilgi puanının daha yüksek olduğuna ilişkin bulgular da yer almaktadır.

Araştırmada, literatürdeki bazı çalışmalara benzer şekilde hemşirelerin yaş, cinsiyet, mesleki deneyim süresi $(4,9,15,22)$, eğitim düzeyi, çalıştıkları klinik $(4,22)$ ve basınç yarası ile ilgili eğitim alma durumunun (14,15,21), BÜÖYT puanını etkilemediği belirlendi. Araştırmadan farklı olarak, mesleki deneyim süresi 10 yıldan fazla olan hemşirelerin (21), 29 yaş ve üstündekilerin ve YBÜ'nde çalışanların (12), cinsiyeti kadın olanların, lisans ve üstü eğitime sahip olanların $(23,28)$, basınç yaralarının önlenmesi ile ilgili eğitim alanların (22), önleme eğitimini en son 6 ay önce alanların (4,23), güncel rehberleri okuyanların (4) tutum puanlarının anlamlı olarak daha yüksek olduğunu ortaya koyan çalışmalar da bulunmaktadır. Farkın nedeni, bu çalışmalara yardımcı hemşirelerin (21), öğrenci hemşirelerin (28), farklı birim ve kurumlarda çalışan hemşirelerin dahil edilmesi $(4,21,23)$, tutum puanını etkileyeceği düşüncesi ile kulak burun boğaz (KBB), üroloji, ve kardiyoloji klinik hemşirelerinin çalışma dışında bırakılması (12) ve basınç yarası ile ilgili farklı içerikte eğitimlerin alınması olabilir. Basınç yaralı hastaya bakım verme deneyimi olan (4), basınç yaralarını önleme girişimlerini düzenli olarak uygulayan ve daha önce bu konuda eğitim almış olan hemşirelerin (14), basınç yaralarını önleme konusunda kendilerini daha yeterli bulduklarını gösteren çalışmalar da bu düşünceleri desteklemektedir.

Hemşirelerin BÜÖBDÖ ile BÜÖYTÖ toplam puan ortalamaları arasında pozitif yönde anlamlı ilişki olduğunu belirten $(5,14)$ literatürden farklı olarak araştırmada, bilgi ve tutum arasında anlamlı ilişki olmadığı belirlendi. Farklı ölçeklerin kullanıldığı benzer çalışmalarda da araştırmamızdan farklı olarak hemşirelerin basınç yarasını önlemeye yönelik bilgi ve tutumları arasında negatif yönde (9) ve pozitif yönde (12) anlamlı ilişki olduğu saptanmıştır. Farkın nedeni, literatürdeki çalışmalara cerrahi klinikleri dışındaki hemşirelerin de dahil edilmesi ve farklı değerlendirme araçlarının kullanılması olabilir. Araştırmamızda, BÜÖBDÖ'nin güvenirlik kat sayısının düşük olması da bilgi ve tutum arasında ilişki saptanmamasına neden olmuş olabilir.

\section{Sınırlılıklar}

Araştırma bazı sınırlılıklara sahiptir. Bunlardan biri, BÜÖBDÖ'nin güvenirlik katsayısının düşük olmasıdır. $\mathrm{Bu}$ sayının düşük olması, ölçek maddelerinin birbirleriyle tutarlı olmadığını ve toplam puana katkılarının düşük olduğunu gösterdiğinden (31) önemlidir. Veri toplama sürecinde bazı hemşireler, BÜÖBDÖ'nin bazı sorularında birden fazla cevabın doğru olduğunu düşündüklerini ifade etti. Örneğin, hemşireler Tema 1'de yer alan ilk sorunun üç seçeneğinin (oksijen yetersizliği, malnütrisyon ve nem) de basınç yarası risk faktörü olduğunu düşündüklerini, içlerinden birini seçmek zorunda kaldıklarını belirtti. Hemşirelerin ifade ettiği gibi bu üç faktör, 2014 yılı basınç yaralarını önleme rehberinde de (1) risk faktörü olarak belirtilmektedir. Ek olarak, ölçeğin orijinal versiyonunda (27) yer alan "bilmiyorum" seçeneğinin Türkçe uyarlamasında (25) yer almaması, 
katılımcıların bilmedikleri soruları da yanıtlamak zorunda kalmasına neden olmuştur. Bu nedenler ölçeğin güvenirlik katsayısını düşürmüş olabilir. Aynı ölçeğin kullanıldığı benzer bir çalışmada da (7), Tema 1'in ilk sorusu gibi bazı soruların tüm yanıtlarının doğru olmasının ve ölçeğin uyarlanmış versiyonunda "bilmiyorum" seçeneğinin olmamasının metodolojik sorunlara neden olduğu belirtilmiştir. Uyarlama versiyonunda "bilmiyorum" seçeneğinin korunduğu bir diğer çalışmada (5), güvenirlik katsayısının 0.86 olarak bulunması da bu düşünceleri desteklemektedir. Manderlier et al. (18), bu ölçeğin güncelliğini yitirdiğini belirtmiş ve bu ölçeği temel alarak 25 soruluk yeni bir araç geliştirmiştir. Bu ölçeğin Türkçe uyarlama çalışması bulunmamaktadır. Gelecek çalışmalarda, güncel ölçeğin Türkçe uyarlamasının yapılması veya rehberler ve kanıt temelli güncel çalışmalar doğrultusunda yeni ölçeklerin geliştirilmesi, basınç yaralarını önlemeye yönelik bilginin daha nitelikli değerlendirilmesini sağlayacağından önemlidir. Araştırmanın diğer bir sınırlılığı da, tek merkezde yürütülmüş olması nedeniyle bulgularının diğer kurumlar için genellenememesidir. Ek olarak araştırma verileri, ilgili kurumun cerrahi klinik ve cerrahi YBÜ hemşireleri ile sınırlıdır. Bu nedenle tüm hemşirelere genellemez. Ancak, araştırma bulgularının literatür ile büyük oranda benzerlik göstermesi, bu bulguların benzer popülasyonlar için geçerli olabileceğine dikkati çekmektedir.

Sonuç olarak; bu araştırma, cerrahi hemşirelerinin basınç yaralarını önlemeye ilişkin bilgilerinin yeterli olmadığını, ancak tutumlarının olumlu olduğunu ortaya koydu. Bu bulgular, basınç yaralarını önlemeye yönelik olumlu tutum geliştirmiş olan cerrahi hemşirelerinin bilgi eksikliklerinin giderilmesinin gerekliliğini göstermektedir. Hemşirelerin basınç yaraları ve önleme girişimlerine ilişkin yeterli bilgiye sahip olması, önlemeye yönelik yetkinliklerinin artırılmasını sağlayarak basınç yarası insidansını azaltacağından önemlidir. Hemşire yöneticiler başta olmak üzere tüm sağlık hizmet yöneticileri, hemşirelerin basınç yaraları ve önleme girişimleri ile ilgili bilgilerini güncel tutmalarını sağlayacak planlamalar yapmalı, önleme girişimlerinin uygulanmasına yönelik yönerge ve protokoller hazırlanmalıdır. Gelecekte, güncel rehberlere dayalı basınç yarası önleme eğitimi sonrası hem eğitim içeriğinin hem de cerrahi hemşirelerinin bilgi, tutum ve uygulamalarının değerlendirildiği yeni çalışmaların yapılması, bu çalışmalarda güncel ve niteliği yüksek değerlendirme araçlarının kullanılması önerilir.
Çıkar Çatışması: Çalışmada herhangi bir çıkar çatışması yoktur.

Finansal Çıkar Çatışması: Çalışmada herhangi bir finansal çıkar çatışması yoktur.

Yazışma Adresi: Serpil Yüksel, Necmettin Erbakan Üniversitesi, Hemşirelik Fakültesi, Hemşirelik Bölümü, Cerrahi Hastalıkları Hemşireliği Anabilim Dalı, Konya, Türkiye

e-mail: yukselserpil1977@gmail.com

\section{KAYNAKLAR}

1. National Pressure Ulcer Advisory Panel (NPUAP), European Pressure Ulcer Advisory Panel (EPUAP), Pan Pacific Injury Alliance (PPPIA). Prevention and treatment of pressure ulcers: quick reference guide. Emily Haesler, ed. Cambridge Media, Osborne Park, Australia, 2014:1-76.

2. Rafiei H, Abdar ME, Iranmanesh S, et al. Knowledge about pressure ulcer prevention, classification and management: Survey of registered nurses working with trauma patients in emergency department. Int J Orthop Trauma Nurs 2014; 18:135-42

3. Nuru N, Zewdu F, Amsalu S, et al. Knowledge and practice of nurses towards prevention of pressure ulcer and associated factors in Gondar University Hospital, Northwest Ethiopia. BMC Nurs 2015;14(34):1-8.

4. Aslan A, Yavuz van Giersbergen M. Nurses' attitudes towards pressure ulcer prevention in Turkey. J Tissue Viability 2016; 25(1):66-73.

5. Tirgari B, Mirshekari L, Forouzi MA. Pressure injury prevention: Knowledge and attitudes of Iranian intensive care nurses. Adv Skin Wound Care 2018;31(4):1-8.

6. Ebi WE, Hirko GF, Mijena DA. Nurses' knowledge to pressure ulcer prevention in public hospitals in Wollega: A crosssectional study design. BMC Nurs 2019;18:20.

7. Gunningberg L, Martensson G, Mamhidir AG, et al. Pressure ulcer knowledge of registered nurses, assistant nurses and student nurses: A descriptive, comparative multicentre study in Sweden. Int Wound J 2015;12(4):462-8.

8. Sarı E. Yoğun bakım hemşirelerinin basınç ülseri hakkındaki bilgi düzeyleri. Akad Geriatri 2013;5:73-9.

9. Yılmazer $\mathrm{T}$, Tüzer $\mathrm{H}$, Erciyas $\mathrm{A}$. Knowledge and attitudes towards prevention of pressure ulcer: Intensive care units sample in Turkey. Turkiye Klinikleri J Nurs Sci 2019; 11(2):140-7.

10. Al Kharabsheh MSAR, Alrimawi RFAR, Al Assaf RM, et al. Exploring nurses' knowledge and perceived barriers to carry out pressure ulcer prevention and treatment, documentation, and risk assessment. Am Int J Contemp Res 2014; 4(4):1129.

11. Iranmanesh S, Tafti AA, Rafiei H, et al. Orthopaedic nurses' knowledge about pressure ulcers in Iran: A cross-sectional study. J Wound Care 2013;22(3):138-40.

12. Charalambous $C$, Koulouri A, Roupa Z, et al. Knowledge and attitudes of nurses in a major public hospital in Cyprus towards pressure ulcer prevention. J Tissue Viability 2019; 28(1):40-5.

13. T.C. Resmi Gazete. Hemşirelik Yönetmeliğinde Değişiklik Yapılmasına Dair Yönetmelik. Sayı:27910,19 Nisan 2011.

14. Beeckman D, Defloor T, Schoonhoven L, et al. Knowledge and attitudes of nurses on pressure ulcer prevention: A cross- 
sectional multicenter study in Belgian hospitals. Worldviews Evid Based Nurs 2011; 8(3):166-76.

15. Demarre' L, Vanderwee K, Defloor T, et al. Pressure ulcers: Knowledge and attitude of nurses and nursing assistants in Belgian nursing homes. J Clin Nurs 2011;21(9-10):1425-34.

16. Uba MN, Alih FI, Kever RT, et al. Knowledge, attitude and practice of nurses toward pressure ulcer prevention in University of Maiduguri Teaching Hospital, Borno State, North-Eastern, Nigeria. Int J Nurs Midwifery 2015;7(4):54-60.

17. Kaddourah B, Abu-Shaheen AK, Al-Tannir M. Knowledge and attitudes of health professionals towards pressure ulcers at a rehabilitation hospital: A cross-sectional study. BMC Nurs 2016;15:17.

18. Manderlier B, Van Damme $\mathrm{N}$, Vanderwee $\mathrm{K}$, et al. Development and psychometric validation of PUKAT 2.0, a knowledge assessment tool for pressure ulcer prevention. Int Wound J 2017;14(6):1041-51.

19. Tallier PC, Reineke PR, Asadoorian K, et al. Perioperative registered nurses knowledge, attitudes, behaviors, and barriers regarding pressure ulcer prevention in perioperative patients. Appl Nurs Res 2017;36:106-10.

20. Kim JY, Lee YJ. A study on the nursing knowledge, attitude, and performance towards pressure ulcer prevention among nurses in Korea long term care facilities. Int Wound J 2019; 16(1):29-35.

21. Tubaishat A, Aljezawi M, Al Qadire M. Nurses' attitudes and perceived barriers to pressure ulcer prevention in Jordan. $J$ Wound Care 2013;22(9):490-7.

22. Ünver S, Fındık ÜY, Kızılcık Özkan Z, et al. Attitudes of surgical nurses towards pressure ulcer prevention. J Tissue Viability 2017;26(4):277-81.

23. Aydoğan S, Çalışkan N. A descriptive study of Turkish intensive care nurses' pressure ulcer prevention knowledge, attitudes, and perceived barriers to care. Wound Manag Prev 2019;65(2):39-47.
24. Qaddumi J, Khawaldeh A. Pressure ulcer prevention knowledge among Jordanian nurses: A cross-sectional study. BMC Nurs 2014;13(1):6.

25. Tülek Z, Polat C, Özkan İ, et al. Validity and reliability of the Turkish version of the pressure ulcer prevention knowledge assessment instrument. J Tissue Viability 2016; 25(4):201208.

26. De Meyer D, Verhaeghe S, Van Hecke A, et al. Knowledge of nurses and nursing assistants about pressure ulcer prevention: A survey in 16 Belgian hospitals using the PUKAT 2.0 tool. J Tissue Viability 2019;28(2):59-69.

27. Beeckman D, Vanderwee K, Demarre L, et al. Pressure ulcer prevention: Development and psychometric validation of a knowledge assessment instrument. Int J Nurs Stud 2010; 47(4):399-410.

28. Beeckman D, Vanderwee K, Demarre L, et al. Pressure ulcer prevention: Development and psychometric evaluation of the attitude towards pressure ulcer prevention instrument (APuP). Int J Nurs Stud 2010;47(11):1432-41.

29. Üstün Y. Basınç ülserlerini önlemeye yönelik tutum ölçeği'nin Türkçe'ye uyarlanması, geçerlik ve güvenirliğinin incelenmesi. İzmir: Ege Üniversitesi, Sağlık Bilimleri Enstitüsü Yüksek Lisans Tezi, 2013:1-172.

30. Saleh MY, Al-Hussami M, Anthony D. Pressure ulcer prevention and treatment knowledge of Jordanian nurses. J Tissue Viability 2013;22(1):1-11.

31. Aker S, Dündar C, Pekşen Y. Ölçme araçlarında iki yaşamsal kavram: Geçerlik ve güvenirlik. O.M.Ü. Tıp Dergisi 2005;22 (1):50-60. 